\title{
健康指標としての訂正平均死亡年令
}

\author{
白 崎 和 夫* 内藤 雅 子* \\ 根 岸 龍 雄* 秋 山 房 雄*
}

\section{Age-Adjusted Average Death-Age as a Comprehensive Health Indicator}

\author{
Kazuo SHIRASAKI** Masako NAITO** \\ Tatsuo NEGISHI** Fusao AKIYAMA**
}

The authors investigated the adaptability of Average Death-Age and Age-Adjusted Average Death-Age as a health indicator, mainly in comparison with some health indicators such as corrected death rate, average life span and infant death rate in several regions with various sizes of population; the whole country, the prefectures and the regions covered by each Health Center in Iwate Prefecture.

The results obtained were as follows:

(1) The longitudinal changes of Average Death-Age for 15 years (1950-1965) in the whole country were very similar to the trends of average life span.

(2) In the case of prefectures, Average Death-Age were sometimes valid but Age-Adjusted Average Death-Age was more reliable as a health indicator.

(3) In the regions covered by a Health Center, Age-Adjusted Average Death-Age was also a useful health indicator but Average Death-Age was a useless one.

Meanwhile, Average Death-Age and Age-Adjusted Average Death-Age are considered to cover the aspect of health level which can not be expressed by another health incators such as corrected death rate, infant death rate etc. Moreover, the calculations of these health indicators are rather simple in its procedure and the collection of necessary basic data can be easily done.

Judging from the results and the facts mentioned above, these two health indicators, especially Age-Adjusted Average Death-Age, will be one of the most useful health indicators in each region with various sizes of population.

\section{1. はじめに}

地域の健康水準を評価する健康指標としては種 々の指標がとりあげられるが，各指標については 精度が高いことのほかに，数值の算定に必要な資 料の入手が容易なこと，执よび算出方法が比較的 簡単であることなどが要求されれる。このため乳
児死亡率や粗死亡率，あるいは WHO の上村・ Swaroop.らによる $\mathrm{PMI}^{11}$ など，死亡統計にもと ら゙く健康指標がとりあげられているが，このよう な特性を有する指標の一つとして平均死亡年令が あげられよう。

健康指標としての平均死亡年令については，こ れまで過去帳や，結核や悪性腫瘍などの特定疾患

*東京大学医学部成人保健学教室

**Department of Adult Health, Faculty of Medicine, University of Tokyo. 
については報告されているが233)，死亡全体につい ての，いわゆる総合的健康指標としてはほとんど 検討されて括らず, 水島も指摘しているごとく 平均寿命ととりちがえて解釈されている場合もみ られる。

一方, この指標の適用の妥当性は, 集団人口の 規模により影響されることが予想され ${ }^{5)}$ ，この指 標により各地域の健康水準を比較する場合には, 訂正死亡染や訂正 $\mathrm{PMI}{ }^{6)}$ などと同様に，対象と なる地域の人口構成に年令補正をを加えて求める いわゆる訂正平均死亡年令が，より精度の高い指 標となることが推察される.

著者らは，種々の人口規模の地域に扣ける平均 死亡年令执よび訂正平均死亡年令の 適用性につい て，地域の健康指標としてすぐれた指標といわれ る訂正死亡率, 平均寿命, および乳児死亡率など との関係を求め，検討を加えたので報告する.

\section{2. 対象と方法}

対象集団は日本全体の場合（昭和 25 年〜 40年の 経年的な変動) 各都道府県単位の場合 (昭和 35 年 および昭和40年) 扣よび保健所管内別の場合（昭 和35年の岩手県の資料) にわけ，これらの地域に おける平均死亡年令拈よび訂正平均死亡年令をと りあげ，おもに平均寿命，訂正死亡率などの指標 との関係を求め, 健康指標としての適用の妥当性 を検討した。

訂正平均死亡年令の年令補正は，5才未満につ いては各才ごとに括こない，5才以上については

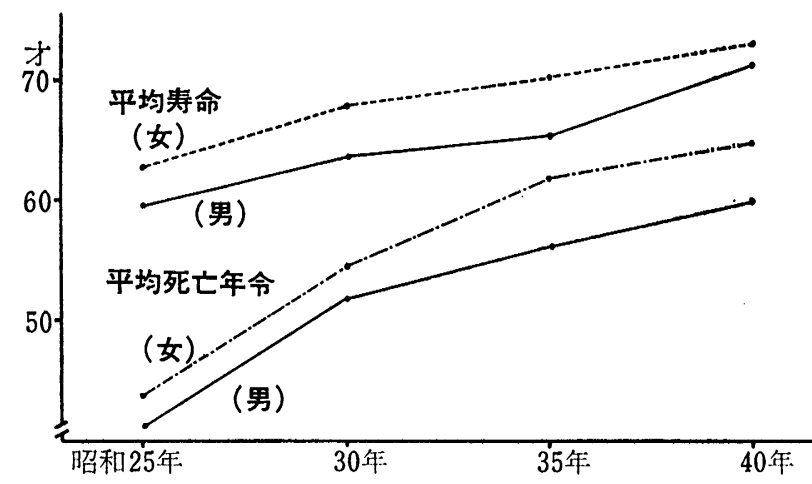

図 1 平均死亡年令および平均寿命の経年変化（全国）
5 才間隔の年令階級別におこなつた.

\section{3. 結果と考察}

図1は日本全体についての平均死亡年令およ び平均寿命を，男女別に昭和 25 年，30年，35年， 40年と経年的に示したものである.この図から平 均死亡年令の経年的な変動は，男女とも平均寿命 の推移と非常に類似した傾向を示し，この指標が 国単位の人口集団を対豖とした 健康水準の評価に 際して有意義な尺度になることが推祭される。

表 1 は各都道附県別の平均死亡年令，訂正平均

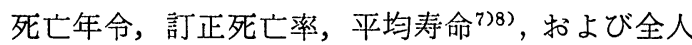
口に対する 60 才以上の老令人口の割合を，昭和35 年.および昭和 40 年について示したものである。こ の表から平均死亡年令は，全体として平均寿命や 訂正死亡率で示される健康水準と類似した傾问を 示すが，東京や大陇，神奈川など都市化の著しい 地域9)の数値が劣つて扔り，平均寿命などの動问 と全く趣きを異にしている。このことは，表にも 示されるようにこれらの地域の老令人口の割合が 少ないことに起因しているものと推察される.図 2 扣よび図 3 は，平均死亡年令，平均青命扣よび 老令人口の割合を都道府県別（昭和 35 年，男子） に，各数值について高い地区 (11県) やや高い地 区（12 県）やや低い地区（12 県）低い地区（11 県) の 4 つの群に組分けしたものであるが，こ れらの図から対象となる地域が 都道府県単位の埸 合には平均死亡年令は老令人口の割合にかなり影 響され，この指標が必らずしも適切な健康指標に はならないことを示唆している。

一方，平均死亡年令に年令補正を加兄 た訂正平均死亡年.令の备都道府県別の比 較については，表1にも示されるように 平均寿命や訂正死亡率などの数值の変動 に非常に類似しており，この関係は図 示することにより一層明確に示される (図 4 ).

つぎに平均死亡年令と平均寿命拈よび 訂正死亡率との相関を昭和 35 年の都道府 県別の資料にもとづいてみると（図 5 お よび図 6 )，前者では男女とも0.45内外 
表 1 都道府県別諸健康指標值

（昭和35年, 40 年）

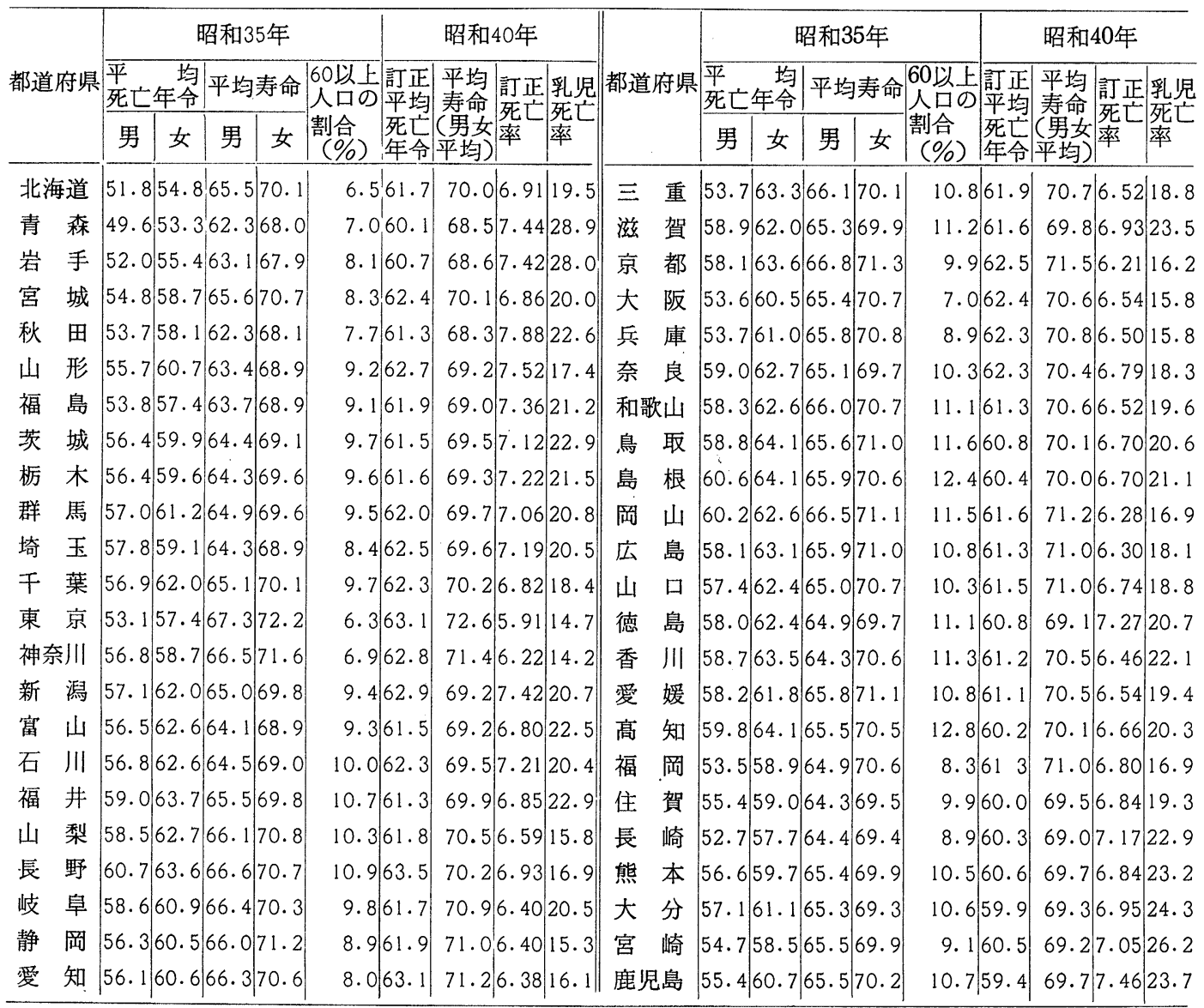

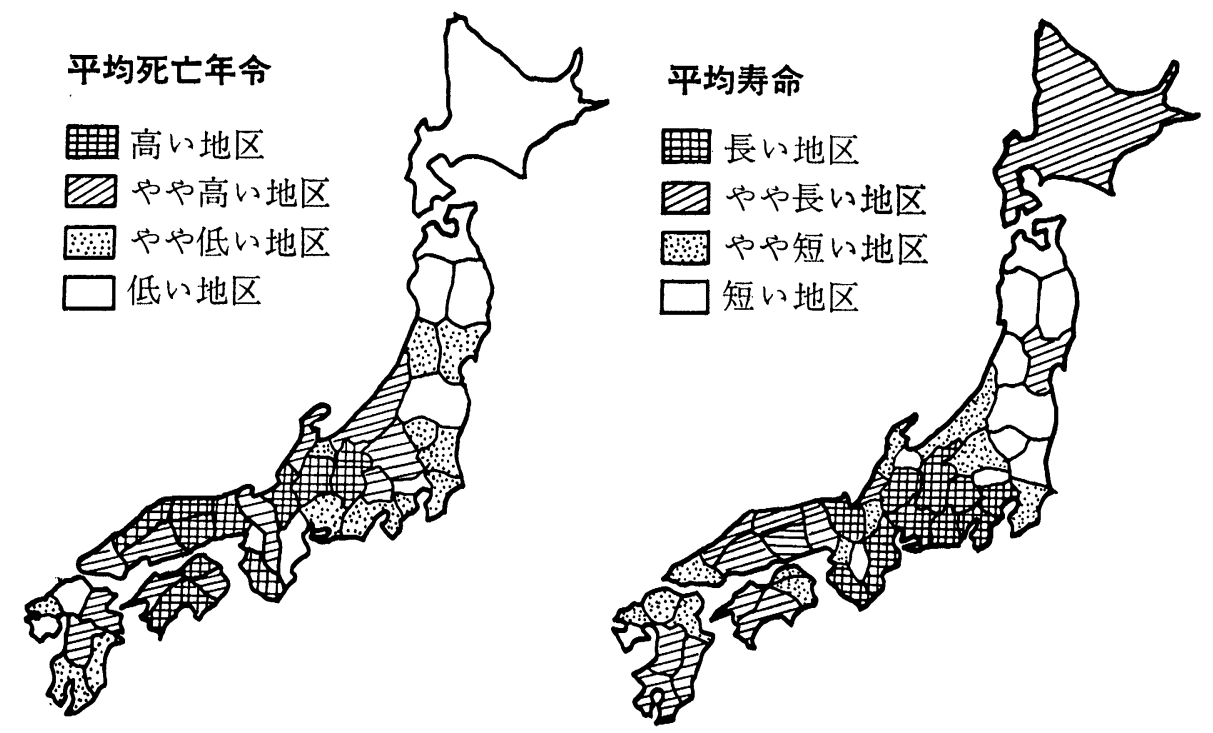

図 2 平均死亡年令と平均寿命との関係（男子）一都道府県別, 昭和35年一 


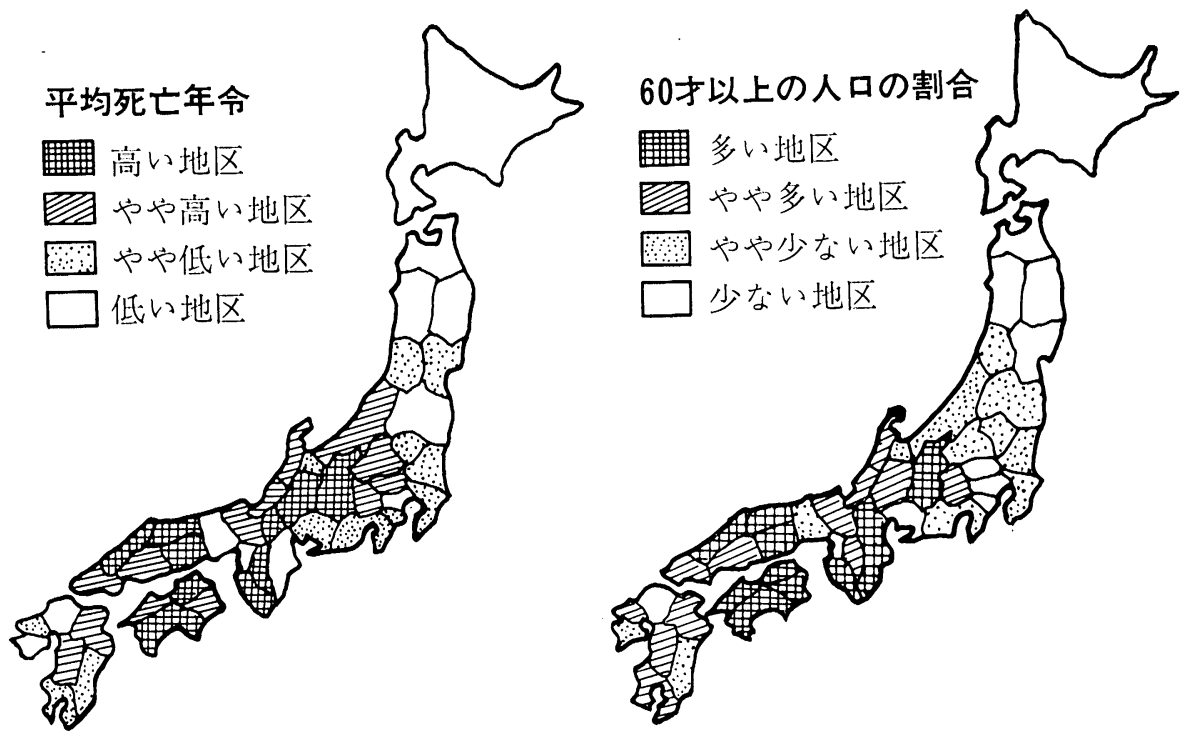

図 3 平均死亡年令と60才以上人口割合との関係（男子）一都道府県別, 昭和35年一

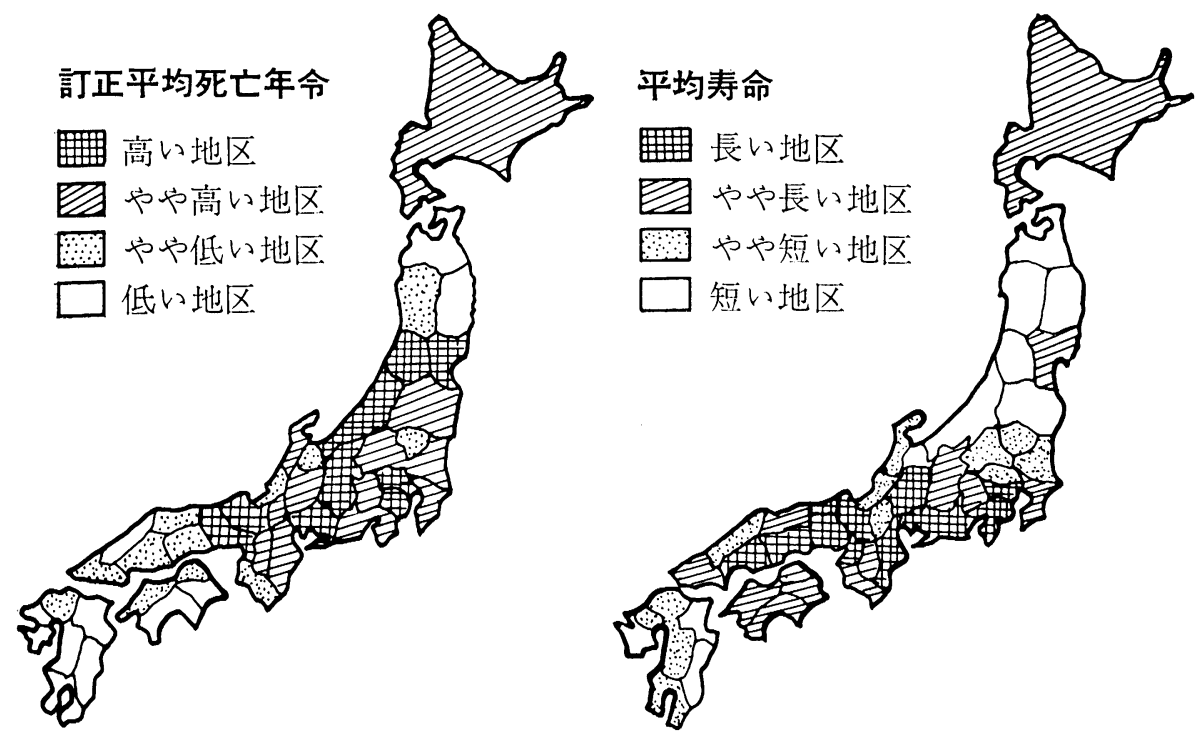

図 4 訂正平均死亡年令と平均寿命との関係 一都道府県別, 昭和40年一 

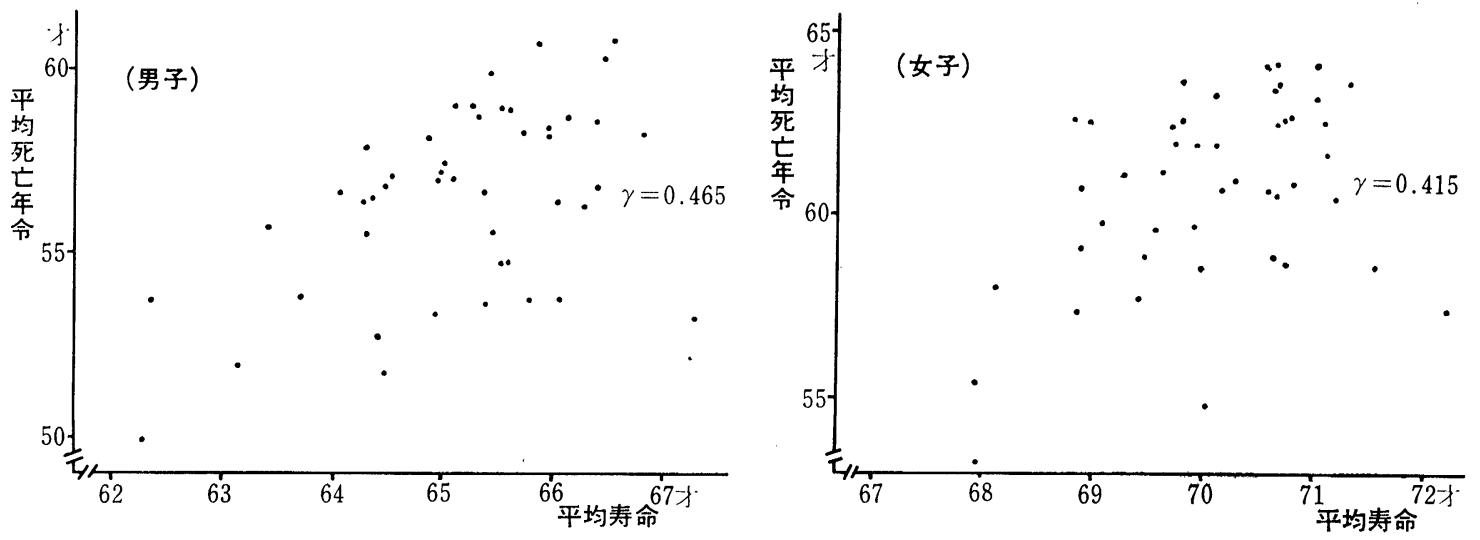

図 5 平均死亡年令と平均寿命との関係 一都道府県別, 昭和35年一
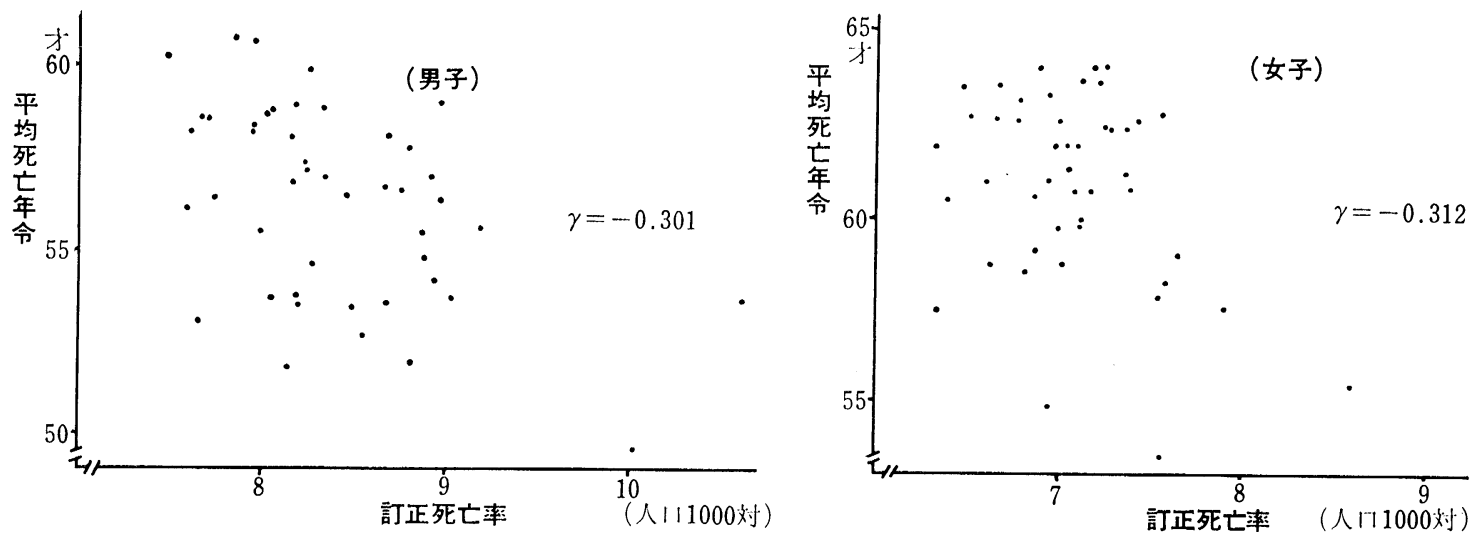

図 6 平均死亡年令と訂正死亡率との関係 一都道府県別, 昭和35年一

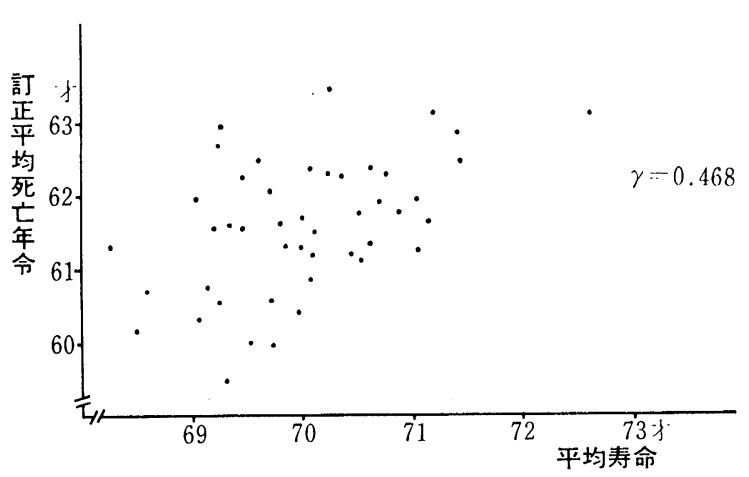

図 7 訂正平均死亡年令と平均寿命との関係 一都道府県別，昭和 40 年一
の相関を示し，後者では一 0.3 程度の 逆相関を 示している. 一方，訂正平均死亡年令と平均寿 命，訂正死亡率および乳児死亡率との関係を昭 和 40 年の資料についてみると（図 7 , 図 8 抽よ び図 9）前二者では平均死亡 年令との関係と 類似した傾向を示し，乳児死亡率との相関は -0.654 と非常に 高い逆相関を示している.

以上のことから，地域が都道府県単位の場合 には, 健康指標としての平均死亡年令は一応の 適用性が認められ，とくに一県内の経年的な変 動の指標としては有意義な指標といえるが，こ の数值に人口の年令補正を加えた 訂正平均死亡 
表 2 岩手県の諸健康指標值と高令人口の割合

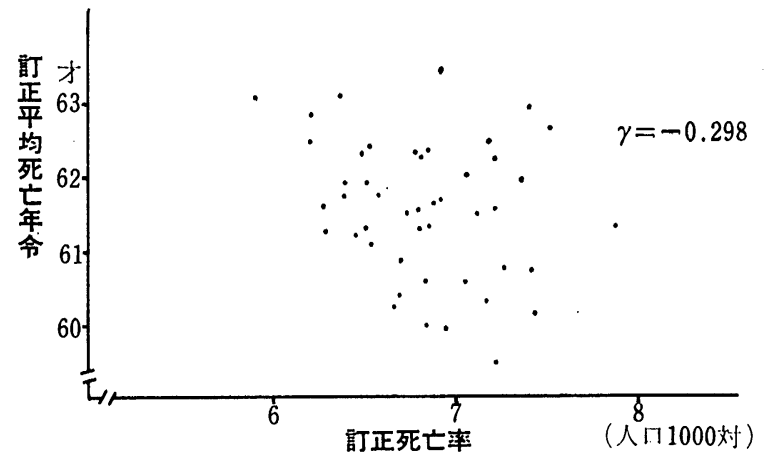
(男子) 一保健所管内別，昭和35年一

図 8 倍正平均死亡年令と訂正死亡率との関係

一都道府県別, 昭和 40 年一

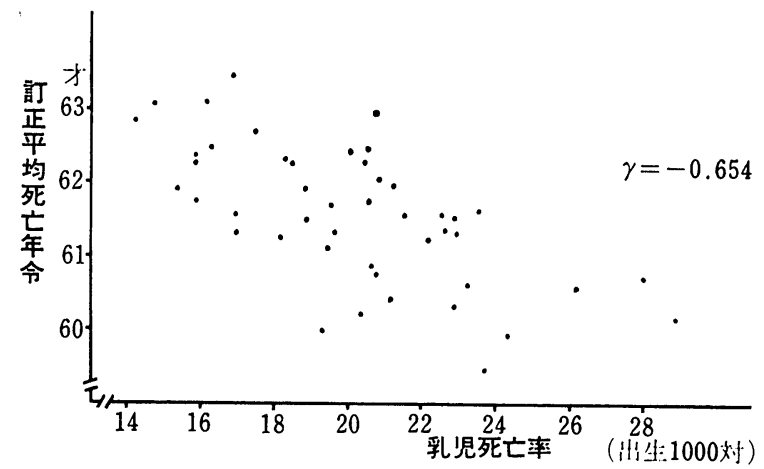

\begin{tabular}{|c|c|c|c|c|c|c|}
\hline & 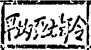 & Eve & 可均素命 & 佂蛋主栾 & 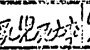 & $\begin{array}{l}6074,5 \\
100\end{array}$ \\
\hline $1(1)$ & 53.03 & $50 ; 2$ & 65.42 & 0.21 & 38.8 & $6.68 \%$ \\
\hline 厉 & $4-9,27-$ & 52.97 & 6,05 & 7.35 & 31.9 & 5.6 .5 \\
\hline 空立 & $4-7.60$ & 49.71 & 69.26 & 8.29 & 39.3 & $7.4 \%$ \\
\hline 药器 & 55.13 & $5 \%: 80$ & $62.9 \%$ & 9.89 & 445 & 8.51 \\
\hline 淡上 & 51.15 & 52.51 & 62.07 & 9.37 & 38.3 & 6.73 \\
\hline 水: & 51.63 & 52.29 & 61.12 & 9.93 & 60.7 & $7.6 \%$ \\
\hline$-\infty, 0$ & 56.30 & 58.61 & 63.50 & 9.20 & $4-2.5$ & 0.95 \\
\hline & 60778 & 50 . & $65.3 \hat{5}$ & 7.68 & $5 \% .1$ & 15,56 \\
\hline & $5 \% .12$ & 4953 & $6 \%: 23$ & 823 & 40.1 & T.:3i \\
\hline & 55.80 & $50.6 \%$ & 63.69 & 98 & 646 & 8.89 \\
\hline $\begin{array}{ll}m \\
3\end{array}$ & $4 \% 21$ & sis.cos & 6296 & $R 35$ & 586 & 9.95 \\
\hline \%笖 & 16525 & 4505 & 61,90 & 9.51 & 660 & 分里: \\
\hline isian & 50.60 & 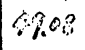 & T6.:0i] & 929 & 66.8 & 858 \\
\hline 嘗于 & 86.85 & $28 \%$ & 6200 & s.t\% & Axy & 6.83 \\
\hline EI & $50.0 \%$ & 650 & 6236 & 800 & 523 & 895 \\
\hline
\end{tabular}

図 9 訂正平均死亡年令と乳児死亡率との関係

一都道府県別, 昭和 40 年一

年令が，より適切に地域の健康水準を表現してい ることがうかがわれる。

表 2 は岩手県（昭和 35 年, 男子）の各保健所管 内地域に招ける諸種の健康指標值之 ${ }^{10)}$, 各指標值 間の相関係数を示している. 各保健所管内の平均 死亡年令について他の健康指標との関係をみると 平均寿命, 訂正死亡率拉よび乳児死亡率とも地域 が都道府県単位の場合に比較して相関度は低下し ており，このことは表にも示されるように，老令 人口の多塞により大きく影響されているものと考 えられる。一方, 訂正平均死亡年令と上述の諸指 標との相関度は，年令補正をおこなわない平均死 亡年令に比較してかなり高い相関を示している. このことから，各保健所管内単位に和ける 健康指 標としては，平均死亡年令はその適用の妥当性が かなり少なく，年令補正を加えた訂正平均死亡年 令を用いる必要のあることが推察される。

以上，平均死亡年令舐よび 訂正平均死亡年令と 諸種の健康指標との関係をみると，全体として両 指標とも平均寿命とはかなり高い相関を示す反面 訂正死亡率との関係は顕著でない。 また，地域の 生活水準や文化水準の尺度として重視されている 乳児死亡率とはきわめて高い相関を示しているこ とが注目される。

WHO の Study Group on the Measurement of Levels of Health ${ }^{33)}$ では, 健康の指標を総合 的な指標と個別的な指標に分け，総合的な指標と して PMI, 平均余命，粗死亡率をあげている．平 均死亡年令の発想法は PMI に近い考えであるが PMI は 0 才死亡と 49 才死亡を同質にとらえる一 方，49才死亡と50才死亡を異質なるのと考えて 抒 り，死亡年令を連続的なものとしてそのまま求 め，その資料にもとづいて数值を算出する平均死 亡年令の方が，PMI に比較して計算の手技は幾 分複雑になるにしても，より適確に地域の健康水 準を表わすものと考えられる。 
また, 訂正平均死亡年令については, 訂正死亡 率や，すで著者らが報告した訂正 $\mathrm{PMI}^{6}$ ) と同じ よ5に年令補正を加觉た健康指標であり，資料の 収集や算定手技の点では平均死亡年令に 比較して 劣つている. しかし，前述の図や表に示されるよ 5 に，対象集団の人口規模が 小さくなるにしたが い平均死亡年令では地域の健康水準を充分に表現 しえない側面があり，この場合には PMI に対す る訂正 PMI と同じょ5に, 訂正平均死亡年令が 有用な指標となりらることがうかがわれる.

わが国比拈硉康水準の評価には，保健所管 内単位の検討が招こなわれることが多いが，この ような小地域における健康指標として適用性の高 い指標に訂正死亡率, 平均寿命, 乳児死亡率, 植

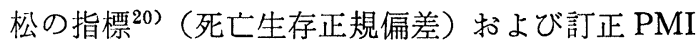
などがあげられるが，本稿で論じた訂正平均死亡 年令は，このような小地域に拄いても充分適用可 能な指標となる。

また，訂正平均死亡年令は健康水準の 尺度とし て，乳児死亡率や訂正死亡率などの指標では表現 出来ない側面を有して和り，資料の入手や算定の 手技も比較的容易なことなどから，総合的健康指 標の一つになることがうかがわれる。

\section{4. まとめ}

健康指標としての平均死亡年令，およびこの数 值に年令補正を加光た訂正平均死亡年令について 対象集団として日本全体の場合（昭和 25 年 40 年 の経年的な変動）各都道府県単位の場合（昭和35 年抒よび昭和 40 年) 抒よび 保健所単位別の場合 （昭和35年の岩手県の資料）をとりあげ，抒もに 平均寿命, 訂正死亡率, 乳児死亡率なぞの 指標之 の関係を求め, 健康指標としての適用の妥当性を 検討した.

その結果，平均死亡年令は国単位の人口集団に 対しては健康指標としての適用性が考克られ， 都道府県単位の場合にも一応の適用性は認められ るが，訂正平均死亡年令の方がより適切に健康水
準を表現することがうかがわれた。一方，地域が 保健所管内単位の場合には，平均死亡年令の適用 の妥当性は認められず，訂正平均死亡年令が有用 な指標となることが推察された。

地域の健康水準の尺度としては，平均寿命や訂 正死亡率, 乳児死亡率, 植松の指標などが精度の 高い指標としてとりあげられているが，平均死亡 年令や訂正平均死亡年令はこれらの指標では表現 出来ない側面を有しており，資料の入手や算定の 手技も比較的容易なことなどから，総合的健康指 標の一つになりらることを示唆した。

本論文の要旨は第33回日本民族衛生学会総会飞招いて 発表した．な拈，岩手県内各地の平均寿命などは，植松 教授による数值を使わしていただいた。ここに深謝した い.

\section{文献}

1) S. Swaroop \&. K. Uemura : Proportional Mortarity of 50 Years and Above, Bull. Wed. Hlth. Org., 17, 439 481 (1957)

2 ) 厚生省統計調査部: 生命表飞よる戦前戦後の死因 別比較, 厚生の指標， 15 ( 6 )， 37〜 43（1968）

3 ) 三好壮秋 - 岡本萬三郎 : 死因別平均死亡年令の死 亡指数としての意義，国民衛生，23，73～82 (1954)

4 ）水島治夫：都市住民の生命力衰退, 都市問題, 56 (11)，16〜30 (1965)

5 ）植松 稔: 人口年令構造と健康指標, 日本公衛誌 15，1033 1037 (1968)

6）白崎和夫・勝沼晴雄・小泉 明：健康指標として の訂正PMI，日本公衛誌，15，473４76(1968)

7 ) 水島治夫・重松峻夫：都道府県別生命表（1959～ 1961)，生命保険文化研究所 (1964)

8 ）水島治夫・重松峻夫・吉田啺夫：都道府県別生命 表 (1965)，生命保険文化研究所 (1968)

9) 木内信蔵編：日本の都市化, 古今書院 (1964)

10）植松 稳: 死亡統計の正規偏差解析, 民族衛生, 30, 74 79 (1964)

11) WHO : Report of the Study Group on the Measurement of Level of Health, WHO tech. rep. ser., 137 (1957) 